\title{
Pubg Fansubtitle: Strategies and Translation Acceptability
}

\author{
Dinda Adventina Laksita Puri \& Truly Almendo Pasaribu \\ advdinda@gmail.com \& trulyalmendo@usd.ac.id \\ English Education Department, Universitas Sanata Dharma
}

\begin{abstract}
This study analysed the subtitling strategies and the acceptability of Indonesian fan subtitle in PewDiePie PUBG video entitled "I WON!!!". There were ten subtitling strategies appearing in the subtitle: Transfer (40.9\%), taming (22.3\%), deletion (11.3\%), expansion (7.9\%), paraphrase (5.8\%), condensation (2.7\%), imitation (2.7\%), resignation (1.2\%), transcription (0.6\%), and decimation $(0.6 \%)$. The researcher also found four translation acceptability degrees in the subtitle: Ideal-acceptable $(80,2 \%)$, acceptable $(3,7 \%)$, unacceptable $(9.8 \%)$, and failed (6.4\%). Therefore, the Indonesian subtitle of "I WON!!!" is considered as acceptable translation because $83.9 \%$ of the translations are acceptable and the effective subtitling strategy to make acceptable translation is transfer.
\end{abstract}

Keywords: fan subtitle, subtitling strategies, translation acceptability, gaming video

\section{Introduction}

YouTube, a social media, connects people around the world by providing fan subtitle contribution feature. Basically, the fans or people who have YouTube accounts can give their fan subtitles in certain videos. Fan subtitle or fansub is a different type of subtitling which is done by amateur translators (Cintas \& Sánchez, 2006). According to Lakarnchua (2015), fansubbing or creating fan subtitles are considered nonprofit work or devotion. Lakaranchua (2015) added that the fans devote to promote the cultural products. Moreover, the huge internet access triggers the growth of fan subbing popularity and people create their amateur subtitle massively (Cintas \& Sánchez, 2006). This fan subtitle contribution feature in YouTube enlarges the potential of fansubbing.

Since fan subtitles are the product of nonprofessional translators, the translations often do not follow the translation standard or the translation strategy (Wang, 2009). Wang added that the fan subtitle members or people who create fan subtitles just translate the language by their own way which they consider to be a "suitable" one. Even though the amateur translators or fan subtitle members do not pay attention to the translation standards and method, translation projects, which are subtitling, require translation strategies and the translation product quality evaluation. Since fan subtitle is Audiovisual Translation (AVT), there is a specific term for the translation strategy in subtitling which is subtitling strategy.

Hariyanto (2005) stated that the purpose of applying subtitling strategy is to deal with some subtitling problems which are language, sociocultural context, time appearance, and limited layout (as cited in Hastuti, 2015). In addition, one of translation product quality assessment is translation acceptability testing. Nababan (2012) stated that translation acceptability is important because in translation there are anything contrary to the norms, rules, and cultures of the target language, the target readers can reject the translation product.

However, the fan subtitle phenomena seem unnoticed in the academic field and the studies about fan subtitles, the new type of 
Audiovisual Translation, are still very little. (Cintas \& Sánchez, 2006). Moreover, the fan subtitles are considered the product of amateur translators (Cintas \& Sánchez, 2006). Wang (2009) added that the point of their translation is finding the most suitable translation of the source language text., but fan subtitles are more flexible and closer to our daily life. Based on those academic reasons and the phenomena of YouTube fan subtitle contribution feature, this study tried to discover the academic point of view which are the subtitling strategies and the acceptability of the Indonesian fan subtitle in the PewDiePie PUBG video entitled "I WON!!!"

\section{Theoretical Description Subtitling Strategies}

Hastuti (2015) stated that strategies are the techniques applied by the translator in transferring the meanings of the words, phrases, clauses from SL to TL. Meanwhile, Fawcett in Bogucki (2004) states that subtitling is transferring the dialogue meaning from SL to TL (as cited in Basari \& Simanjuntak, 2016). According to Basari and Simanjuntak (2016), translator transfers the messages of the source language by applying the strategies which make the target texts TL acceptable. Therefore, subtitling strategies are the techniques which are used in transferring the meaning of SL to TL to overcome the subtitling problem in order to create the acceptable subtitle. Gottlieb (1992), an experienced translator in the area of audiovisual translation, composed some fundamental subtitling strategies classifications. The example of the ten subtitling strategies proposed by Gottlieb (1992) as cited in Basari and Simanjuntak (2016).

Table 1 Translation Strategies

\begin{tabular}{ll|}
\hline \multicolumn{1}{c}{ Translation Strategies } & \multicolumn{1}{c}{ Explanation } \\
\hline Expansion & \multicolumn{1}{c}{$\begin{array}{l}\text { This strategy is applied when the source language text needs } \\
\text { an explanation because of some cultural differences which } \\
\text { cannot be replaced in the target language. }\end{array}$} \\
\hline Paraphrase & $\begin{array}{l}\text { Paraphrase is applied when the same syntactical rules in } \\
\text { transferring the meaning from SL to TL is not used by the } \\
\text { translators. This strategy is used to make the subtitle in TL } \\
\text { easy to understand and enhance the readability. }\end{array}$ \\
\hline Transfer & $\begin{array}{l}\text { This strategy transfers the meaning from SL to TL in a } \\
\text { complete and correct way. The translators directly transfer the } \\
\text { meaning by the literal word meaning. The purpose of this } \\
\text { strategy is to maintain the source text structure. }\end{array}$ \\
\hline Imitation & $\begin{array}{l}\text { Imitation keeps the same form of the SL. This strategy usually } \\
\text { applies in dealing with proper nouns such as the name of } \\
\text { places and people. }\end{array}$ \\
\hline Transcription & $\begin{array}{l}\text { Transcription is applied to deal with unusual terms, nonsense } \\
\text { language, or third language in a source text. }\end{array}$ \\
\hline Dislocation & $\begin{array}{l}\text { This strategy is used when there are some special effects in the } \\
\text { source text that are more significant than the translation } \\
\text { contents. }\end{array}$ \\
\hline Condensation & $\begin{array}{l}\text { Condensation is the strategy to create the shorter text by } \\
\text { removing redundancy on the utterance in order to solve the } \\
\text { subtitle line limitation problem. }\end{array}$ \\
\hline Decimation & $\begin{array}{l}\text { Decimation is the extreme form of condensation or the } \\
\text { extensive reduction of message which is followed by the } \\
\text { reduction of its important expression and parts. The } \\
\text { decimation strategy is applied due to the discourse speed or } \\
\text { the situation in a quarrel when the actor speaks so fast. }\end{array}$ \\
\hline
\end{tabular}




\begin{tabular}{ll|}
\hline \multicolumn{1}{c}{ Translation Strategies } & \multicolumn{1}{c}{ Explanation } \\
\hline Deletion & $\begin{array}{l}\text { Deletion is eliminating some text parts such as repetition, } \\
\text { filler, and question tag. }\end{array}$ \\
\hline Resignation & $\begin{array}{l}\text { Resignation is applied when the solution of a translation } \\
\text { problem cannot be found. The meaning of the source text may } \\
\text { be lost during the process. }\end{array}$ \\
\hline Taming & $\begin{array}{l}\text { Taming strategy is used to translate the taboo or rude words } \\
\text { in order to create an acceptable translation in the TL. }\end{array}$ \\
\hline
\end{tabular}

Another set of subtitling strategy is proposed by Hariyanto (2005). Hariyanto (2005) proposed ten subtitling strategies which are paraphrase, imitation, expansion, transfer, condensation, transcription, deletion, decimation, resignation, and taming (as cited in Hastuti, 2015). The different point between Hariyanto's and Gottlieb's subtitling strategies is that Hariyanto (2005) does not explore the dislocation subtitling strategy, but he explains the taming subtitling strategy to make the translation more acceptable for TL users.

Evaluating the acceptability of particular translation is thought-provoking and tricky at the same time. According to Nababan (2012), translation acceptability refers to the translation that should reflect the norms, rules, and cultures of the target language. He states that translation acceptability is important because in the translation containing anything contrary to the norms, rules, and cultures of the target language, the target reader can reject the translation product. Another similar idea of the acceptable translation is proposed by Siregar (2016), acceptability in translation related to the reasonableness of the translation, the use of words and terms that are standard and familiar for its disciplinary. The aim of acceptability is to assess the naturalness of translation, whether the form of the translated text is natural and equivalent with the target text. A text can be determined as acceptable when it conforms these criteria and the meaning in ST is conveyed accurately; the meaning in target text uses a standard grammatical pattern and vocabulary and the translated text should represent an ordinary context in the target text. According to Larson (1984), acceptable translation has several criteria:

a. Using the target language in the normal forms. b. Communicating the same meaning which is understood in the SL to the target language as much as possible.

c. Maintaining the dynamics of the source text language.

Moreover, he composes three criteria to classify translation products. The three criteria proposed by Larson (1984) are

- Accurate (A): maintaining the message and conveying the same meaning of the SL to TL.

- Clear (C): having a clear meaning and stating all aspect.

- Natural (N): using the natural form which is appropriate in the TL.

In addition, Larson (1984) explained the three criteria. Firstly, being accurate means that the translation transfers the meaning from SL to TL correctly and preserves the meaning from SL to TL by giving necessary addition and deletion. Secondly, being clear means the language form in TL makes the message of the SL understandable as easy to understand the SL as possible. Finally, being natural means that the grammatical forms which are used in the TL are normally used so that the translation is natural and appropriate in the sociocultural context of the TL.

The classification of the translation products are ideal and acceptable translations (I-Acc), acceptable translations (Acc), Unacceptable translations (Uncc), and failed translations $(\mathrm{F})$. If a translation meets all the criteria (A, N, and $\mathrm{C}$ ), it is considered Ideal and Acceptable (I-Acc). If it has two out of the three categories, it is categorized as Acceptable (Acc). If it only possesses one out of the three either it is $\mathrm{A}$, or $\mathrm{N}$, or $\mathrm{C}$, it is considered as Unacceptable (Uncc). Then, if a translation possessing none of the criteria, it is Failed (F). 


\section{Fan Subtitle in Youtube}

There are some YouTube channels which let their viewers contribute closed captions, subtitles, or description translations in the videos of their channels. The contributed translations are accessible on the video watch page. In order to see it, the icon [CC] can be clicked in the video player. For instance, if you would like to see the Indonesian subtitle for a video, you can click [CC] and choose Indonesian. Moreover, the contributed translations need to be approved by the video owner. Furthermore, the translators acquire the credit which appears on the video description because of their translation contributions. YouTube also states that the translator contribution might be combined with other translator works in a video until the subtitles are ready to be reviewed. The other translators are able to edit by adding or improving the subtitle. However, the edited subtitle needs to go to the review process from the video owner (the YouTuber) and get the approval from the video owner to be displayed.

\section{Methodology}

This study applied a descriptive qualitative method which is document analysis. Atmowardoyo (2018) stated that descriptive research is a method of research which accurately describes the existing phenomena in a systematic way. According to Porter (2007), as quoted in Crescentini (2009), qualitative research is a method which means using the words to identify such information that is gathered and analyzed. In addition, Bowen (2009) stated that document analysis is a systematic procedure for reviewing or evaluating documents, both printed and electronic. Documents contain text (words) and images that have been recorded without a researcher's intervention. The researcher wanted to describe the subtitling strategies and the translation acceptability of the fan subtitle phenomenon in YouTube, specifically in PewDiePie PUBG video entitled "I WON!!!"

In this study, the data were the Indonesian fan subtitles and the transcription. In addition, the type of data in this study was utterances and their translations. The Indonesian fan subtitles were downloaded from www.youtube.com in PewDiePie PUBG video entitled "I WON!!!". The researcher downloaded the documents by using www.downsub.com, which is a subtitle download generator. The Indonesian fan subtitles from the video entitled "I WON!!!" are translated by Nore, Watcher Udin, Scodz, and Abi Harris Sumapraja. Therefore, the source of the data was the video entitled "I WON!!!"

The English utterances which are the transcription of the video entitled "I WON!!!" were typed by using InqScribe software. InqScribe software is a software which helps to transcribe what the speakers say in a video. In other words, the sources of the English transcription were the video entitled "I WON!!!" from PewDiePie channel which was uploaded in www.youtube.com on 11 June 2017.

The overall depiction of the data gathering technique and the data analysis technique could be understood from the Figure 4. First of all, the researcher gathered the data for the data analysis process. The researcher started by watching the PewDiePie PUBG video "I WON!!!" twice, once without the Indonesian subtitle and once with the Indonesian subtitle. In gathering the source language text, the researcher transcript the spoken dialogue and the written text on the video "I WON!!!". After the source language texts were gathered, the researcher compared the source language text and the target language text which is the Indonesian subtitle of the video "I WON!!!" by paying attention to the time appearance of the subtitle and the spoken dialogue.

The analysis of the Indonesian fan subtitle was done in two ways. The first way was applied to answer the first research question about the subtitling strategy used in the Indonesian fan subtitle. In this process, the comparison between the Indonesian fan subtitle and the transcript of the SL was analyzed. The analysis was done based on Gottlieb's and Hariyanto's subtitling strategies theories. There are ten subtitling strategies proposed by Gottlieb (1992). The second way was the translation acceptability assessment which was done to answer the second research question. The second goal is to know how 
acceptable the Indonesian fan subtitle of PewDiePie PUBG video. In order to answer it, the source language data and the target language data were analyzed by giving check mark on the accomplished criteria of the Larson's (1984). The criteria are accuracy, clarity, and naturalness. In addition, the analyzed data were categorized based on the acceptability degrees which are idealacceptable, acceptable, unacceptable, and failed.

After the analysis by the researcher was done, the result of the analysis was checked again by the researcher to make a better result. Then, the data analysis was validated to the translation expert to get a better result. The validation was done twice. The first one was in the discussion form. Meanwhile, the second one was done in the written form by using data analysis validation rubric format. After obtaining the result from the validator, the researcher reported the result of the data analysis.

\section{Discussion}

There are ten subtitling strategies appeared in the fan subtitle of PewDiePie PUBG video entitled "I WON!!!" as can be seen in the Table 1 . The subtitling strategies are transfer, taming, deletion, paraphrase, expansion, condensation, imitation, resignation, transcription, and decimation. The most dominant subtitling strategy in the fan subtitle is transfer strategy with 134 data (40.9\%) out of 328 data. Transfer strategy becomes the most dominant subtitling strategy which appears in the fan subtitle because the utterances in the source language are mainly can be translated by the literal word meaning. Taming strategy appears in 72 data $(22 \%)$ out of 328 data. There are 37 data (11.3\%) which apply deletion strategy. Expansion strategy appears in 26 data (7.9\%). Paraphrase strategy is captured in 20 data (6.1\%).

There are 17 data which shows the use of resignation strategy (4.9\%). Meanwhile, the frequency number of condensation and imitation are the same in which each of the strategies has 9 data out of 328 data (2.7\%). Moreover, transcription and decimation are the least frequent subtitling strategies in which both have 2 data out of 328 data. The decimations strategy rarely appears because the utterances in the SL are relatively short and the utterances which appear in the fast discourse speed do not need extensive reduction. Meanwhile, the transcription strategy only appears in 2 data out of 328 data because there are no abundant third language or non-sense word.

Table 2: The Subtitling Strategies of the Fan Subtitle "I WON!!!"

\begin{tabular}{c|l|c|c|}
\hline No & Subtitling Strategy & Frequency & Percentage \\
\hline $\mathbf{1}$ & Transfer & 134 & $40.9 \%$ \\
\hline $\mathbf{2}$ & Taming & 73 & $22.3 \%$ \\
\hline $\mathbf{3}$ & Deletion & 26 & $11.3 \%$ \\
\hline $\mathbf{4}$ & Expansion & 19 & $7.9 \%$ \\
\hline $\mathbf{5}$ & Paraphrase & 17 & $5.8 \%$ \\
\hline $\mathbf{6}$ & Resignation & 9 & $2.2 \%$ \\
\hline $\mathbf{7}$ & Condensation & 9 & $2.7 \%$ \\
\hline $\mathbf{8}$ & Imitation & 2 & $0.6 \%$ \\
\hline $\mathbf{9}$ & Transcription & 2 & $0.6 \%$ \\
\hline $\mathbf{1 0}$ & Decimation & 328 & $100 \%$ \\
\hline
\end{tabular}

The researcher provides the explanation of the ten subtitling strategies which appear in the findings, the analysis discussion of the ten subtitling strategies and the example from the findings in the next part of this study. 


\section{Transfer}

The subtitling case below shows the examples of transfer subtitling strategy from the findings. In datum number 76, the translator translates each word of the text accurately by transferring the literal meaning of each word and maintaining the source language form. Thus, the meanings from the source language texts to the target language texts are translated by implementing the transfer subtitling strategy.

Table 3: Examples of transfer strategy

\begin{tabular}{|c|c|c|c|}
\hline SL Code & SL & TL Code & TL \\
\hline $\begin{array}{l}\text { 76/SL/t.03:59.20 } \\
\text { - 04:01.04 }\end{array}$ & $\begin{array}{l}\text { Please don't hurt } \\
\text { me! }\end{array}$ & $\begin{array}{l}\text { 76/TL/t.03:59.20 - } \\
04: 01.30\end{array}$ & $\begin{array}{l}\text { Kumohon } \\
\text { jangan sakiti } \\
\text { aku! }\end{array}$ \\
\hline $\begin{array}{l}\text { 94/SL/t.05:05.12 } \\
-05: 07.10\end{array}$ & $\begin{array}{l}\text { Looks like a } \\
\text { Swedish little } \\
\text { village, doesn't it? }\end{array}$ & $\begin{array}{l}\text { 94/TL/t.05:05.12 - } \\
\text { 05:07.30 }\end{array}$ & $\begin{array}{l}\text { Kelihatannya } \\
\text { seperti desa } \\
\text { kecil Swedia, } \\
\text { 'kan? }\end{array}$ \\
\hline
\end{tabular}

In datum number 94, the translator simply transfers each word literal meaning from SL to TL. The question tag in the SL which is "doesn't it?" is also transferred into "kan?". Therefore, the translator uses the transfer strategy because every aspect in the SL is translated correctly and completely to TL by the literal word meaning.

\section{Taming}

The subtitling case below shows the implementation of taming subtitling strategy. In the datum number 243, the speaker in the SL says, "Fuck! I can't aim! Goddammit!", but the translator translates the message from SL to TL into "Berengsek! Aku tak bisa membidik dengan baik! Sialan!". In this subtitling case, the translator applies taming strategy to translate the profanities. The first profanity is the word "Fuck" which is considered sexual taboo word and the second profanity is "Goddammit!" which is included as blasphemy.

Table 4: Examples of taming strategy

\begin{tabular}{|c|c|c|c|}
\hline SL Code & SL & TL Code & TL \\
\hline $\begin{array}{l}243 / \mathrm{SL} / \mathrm{t} .13: 34 \\
.15-13: 37.09\end{array}$ & $\begin{array}{l}\text { Fuck! I can't aim! } \\
\text { Goddammit! }\end{array}$ & $\begin{array}{l}\text { 243/TL/t.13: } \\
34.15- \\
13: 37.38\end{array}$ & $\begin{array}{l}\text { Berengsek! Aku tak bisa } \\
\text { membidik dengan baik! } \\
\text { Sialan! }\end{array}$ \\
\hline $\begin{array}{l}308 / \mathrm{SL} / \mathrm{t} .16: 34 \\
.01-16: 35.25\end{array}$ & $\begin{array}{l}\text { Look how tiny this } \\
\text { fucking asshole is. }\end{array}$ & $\begin{array}{l}\text { 308/TL/t.16: } \\
34.01- \\
16: 36.52\end{array}$ & $\begin{array}{l}\text { Lihatlah lingkaran kecil } \\
\text { ini. }\end{array}$ \\
\hline
\end{tabular}

In datum number 308, the translator applies taming strategy to translate the phrase "fucking asshole". The phrase "fucking asshole" is considered profanity or swearing word which refers to sexual taboo word and body part. In datum 308 , the context in which the speaker said the utterance was when the blue zone (the area which is not safe) was shrinked to the safe zone which was symbolized by the white circle on the map. Therefore, the translator translates the phrase "fucking asshole" from the SL to the TL into lingkaran. 


\section{Deletion}

The subtitling case below shows the examples of deletion subtitling strategy from the finding. In datum number 67, the speaker says, "Don't worry about it", but the translator translates the English utterance from SL to TL into "Jangan khawatir". The translator omits the phrase "about it" from the SL because the translator finds the phrase to be less important.

Table 5: Examples of deletion strategy

\begin{tabular}{llll|}
\hline \multicolumn{1}{c}{ SL Code } & \multicolumn{1}{c}{ SL } & \multicolumn{1}{c}{ TL Code } & \multicolumn{1}{c}{ TL } \\
\hline 67/SL/t.03:30.08 & Don't worry about it. & \multicolumn{1}{c}{ 67/TL/t.03:30.08 } & Jangan \\
- 03:31.14 & & $-03: 31.14$ & khawatir. \\
\hline 9/SL/t.00:27.00 - & Oh shit, oh shit, oh & 9/TL/t.00:27.00 - & Sial. \\
00:30.12 & shit! & $00: 30.12$ & \\
\hline
\end{tabular}

In datum number 9 of the source language, the speaker says, "Oh shit, oh shit, oh shit" and the translator translates the SL to TL into "Sial.". The speaker does some repetitions of the interjection "Oh shit".

\section{Expansion}

There is an expansion in datum number 266 in which the translator gives addition to the meaning of "Five people" into "Tersisa 5 orang!". Based on the context of PUBG gameplay, after the determined time, the safe zone is getting smaller in the purpose to make the players meet each other accidentally and kill the other players so that there is a winner of the match or the last man standing on the island. When the speaker says, "Five people", the utterances refer to the total number of the survivors on the island at the time when the speaker says the utterances.

Table 6: Examples of expansion strategy

\begin{tabular}{|c|c|c|c|}
\hline SL Code & SL & TL Code & TL \\
\hline $\begin{array}{l}\text { 266/SL/t.14:47 } \\
.01-14: 49.18\end{array}$ & $\begin{array}{l}\text { This.. this circle is } \\
\text { getting so tiny. } \\
\text { Five people! }\end{array}$ & $\begin{array}{l}\text { 266/TL/t.14:4 } \\
7.01-14: 49.60\end{array}$ & $\begin{array}{l}\text { Lingkaran ini } \\
\text { semakin mengecil! } \\
\text { Tersisa } 5 \text { orang! }\end{array}$ \\
\hline $\begin{array}{l}\text { 37/SL/t.01:29. } \\
10-01: 30.16\end{array}$ & $\begin{array}{l}\text { This is the fucking } \\
\text { one. }\end{array}$ & $\begin{array}{l}\text { 37/TL/t.01:29. } \\
10-01: 30.16\end{array}$ & $\begin{array}{l}\text { Inilah ronde yang } \\
\text { kunantikan. }\end{array}$ \\
\hline
\end{tabular}

In datum number 37, the word "fuck" in the SL can be derived into many word classes, but there is no word like that in Indonesian (TL) which can be the equivalent of the word "fuck". Moreover, the word "one" in English (SL) can have many meanings due to the contextual meaning (referring to the context). Thus, the translator explains the meaning of "the fucking one" by providing supplementary information in the TL that "the fucking one" is "ronde yang kunantikan" in order to make the translation acceptable in the TL.

\section{Paraphrase}

The subtitling cases below show the examples of paraphrase subtitling strategy from the findings.

Table 7: Examples of paraphrase strategy

\begin{tabular}{l|lll|}
\hline SL Code & SL & TL Code & TL \\
\hline 272/SL/t.15:07.15 & Shit! It's tiny! & 272/TL/t.15:07.15 & Sial! Kecil \\
$-15: 09.03$ & \multicolumn{1}{l}{ 15:09.32 } & sekali! \\
\hline 114/SL/t.05:59.25 & I'm gonna go & $114 /$ TL/t.05:59.25 & Aku akan \\
$-06: 00.26$ & around. & $-06: 01.28$ & berputar. \\
\hline
\end{tabular}


In datum number 272, the translator paraphrase the sentence "It's tiny!" to adjective phrase "Kecil sekali!" because if the pronoun "it" is translated, the pronoun should be explained in Indonesian based on the contextual meaning. In the datum number 114, the contextual meaning of the verb phrase "go around" in the SL is not the same as "pergi berkeliling" in the TL, but the meaning of the verb phrase refers to the verb phrase "turn around" which has the meaning as "berputar" in the target language. The verb phrase "berputar" is more suitable with the context rather than "pergi berkeliling".

\section{Resignation}

In datum number 110, the translator applies the resignation strategy because even though the word "fucking" in the SL as the adjective has the meaning as the act of swearing, the word "kek" is nonsense in English.

Table 8: Examples of resignation strategy

\begin{tabular}{|c|c|c|c|}
\hline SL Code & SL & TL Code & TL \\
\hline $\begin{array}{l}\text { 110/SL/t.05:48.09 - } \\
05: 49.16\end{array}$ & Fucking kek! & 110/TL/t. & (Untranslatable) \\
\hline $\begin{array}{l}\text { 187/SL/t.10:06.00 - } \\
\mathbf{1 0 : 0 6 . 2 8}\end{array}$ & Hey please & 187/TL/t. & (Untranslatable) \\
\hline
\end{tabular}

In datum number 184, the speaker says, "Hey please", but the translator does not translate the utterance from SL. In fact, the meaning of the utterance "Hey please" is not in the literal meaning because the situation in the video does not match with the literal meaning of the utterance "hey please".

\section{Condensation}

In datum number 271, the translator removes the redundancy in the SL utterances which are "Oh, it's getting... Oh, it's already getting..". In other words, the translator reduces the meaning of the SL because the utterances in the SL have a similar meaning.

Table 9: Examples of condensation strategy

\begin{tabular}{llll|}
\hline \multicolumn{1}{c}{ SL Code } & \multicolumn{1}{c}{ SL } & \multicolumn{1}{c}{ TL Code } & \multicolumn{1}{c}{ TL } \\
\hline $\begin{array}{l}\text { 271/SL/t.15:03.10 } \\
-15: 06.12\end{array}$ & $\begin{array}{l}\text { Oh, it's } \\
\text { getting... Oh } \\
\text { it's already } \\
\text { getting }\end{array}$ & $\begin{array}{l}\text { 271/TL/t.15:03.10 } \\
\text { smaller! }\end{array}$ & $\begin{array}{l}\text { Lingkarannya } \\
\text { semakin kecil! }\end{array}$ \\
\hline $\begin{array}{l}\text { 19/SL/t.00:52.03 - } \\
\text { 00:53.11 }\end{array}$ & $\begin{array}{l}\text { You guys } \\
\text { come here } \\
\text { often? }\end{array}$ & $\begin{array}{l}\text { 19/TL/t.00:52.03 - } \\
\text { o0:53.11 }\end{array}$ & $\begin{array}{l}\text { Kalian sering } \\
\text { datang ke } \\
\text { sini? }\end{array}$ \\
\hline
\end{tabular}

In datum number 19, the translator reduces the redundancy of the word "guys", so that the phrase "You guys" is translated into "Kalian". Moreover, the time duration for the subtitle in the TL is only around 1 second which makes the translator need to adjust the character per line to make a readable subtitle.

\section{Imitation}

The subtitling cases below show the implementation of imitation subtitling strategy. In datum number 1 , the translator uses imitation subtitling strategy to maintain the same form of the word "Steam" from SL to TL because "Steam" is the name of world-wide game provider. 
Table 10: Examples of imitation strategy

\begin{tabular}{|c|c|c|c|}
\hline SL Code & SL & TL Code & TL \\
\hline $\begin{array}{l}\text { 1/SL/t.00:00.02 - } \\
\text { 00:02.08 }\end{array}$ & $\begin{array}{l}\text { What's the most } \\
\text { popular game on } \\
\text { Steam? }\end{array}$ & $\begin{array}{l}\text { 1/TL/t.00:00.02- } \\
\text { 00:02.08 }\end{array}$ & $\begin{array}{l}\text { Permainan apa } \\
\text { yang } \\
\text { terpopuler di } \\
\text { Steam? }\end{array}$ \\
\hline $\begin{array}{l}\text { 21/SL/t.00:56.00 } \\
-00: 56.29\end{array}$ & $\begin{array}{l}\text { Is that } \\
\text { Markiplier? }\end{array}$ & $\begin{array}{l}\text { 21/TL/t.00:56.00 } \\
-00: 56.29\end{array}$ & $\begin{array}{l}\text { Apa itu } \\
\text { Markiplier? }\end{array}$ \\
\hline
\end{tabular}

In datum number 21, the translator maintains the original SL form which is "Markiplier" because "Markiplier" is the name of a famous American YouTuber.

\section{Transcription}

Transcription is applied to translate third language in a source text. The subtitling cases below shows the implementation of transcription subtitling strategy.

Table 11: Examples of transcription strategy

\begin{tabular}{lllll}
\hline \multicolumn{1}{c}{ SL Code } & \multicolumn{1}{c}{ SL } & \multicolumn{1}{c}{ TL Code } & \multicolumn{1}{c}{ TL } \\
\hline 90/SL/t.04:48.02 - & Domo arrigattou. & 90/TL/t.04:48.02 & Terima kasih. \\
04:49.21 & & $04: 50.16$ & \\
\hline 174/SL/t.09:18.20 & Sayonara, & 174/TL/t.09:18.20 & Selamat tinggal, \\
$-09: 19.25$ & motherfucker! & $-09: 20.38$ & bajingan. \\
\hline
\end{tabular}

In datum number 90 and 174, the utterances "Domo Arrigattou" and "sayonara" are from Japanese which is considered as the third language in the subtitling process. Therefore, in these subtitling cases, the translator applies transcription strategy.

\section{Decimation}

This strategy is used to avoid redundancy in the TL. The subtitling case below shows the implementation of the decimation subtitling strategy:

Table 12: Examples of decimation strategy

\begin{tabular}{llll|}
\hline \multicolumn{1}{c}{ SL Code } & \multicolumn{1}{c}{ SL } & \multicolumn{1}{c}{ TL Code } & \multicolumn{1}{c}{ TL } \\
\hline 127/SL/t.06:51. & $\begin{array}{l}\text { I don't know what } \\
\text { fuck to do. What do I } \\
\text { d1 - 06:53.08 }\end{array}$ & $127 /$ TL/t.06:51.2 & $\begin{array}{l}\text { Aku tak tahu apa } \\
\text { yang harus } \\
\text { dilakukan. }\end{array}$ \\
\hline \begin{tabular}{l|l|l|} 
d64/SL/t.08:43. \\
16- 08:44.20
\end{tabular} & $\begin{array}{l}\text { I'll pick my battles, } \\
\text { alright? I'll pick my } \\
\text { fucking battles }\end{array}$ & $\begin{array}{l}\text { 164/TL/t.08:43.1 } \\
6-08: 44.20\end{array}$ & $\begin{array}{l}\text { Akan kutarik } \\
\text { perlawananku. }\end{array}$ \\
\hline
\end{tabular}

In datum number 127, the utterances in the SL "I don't know what fuck to do. What do I do?" is reduced into "Aku tak tahu apa yang harus dilakukan" due to the time duration of the utterances. In the datum number 164, the translator removes the redundancy in the SL which is "I'll pick my battles, alright?". Since the utterances are similar but both convey different meanings. The first utterance of the SL is "I'll pick my battles, alright?" which shows the expression of certainty. Meanwhile, the second utterance which is "I'll pick my fucking battles" shows the expression of anger because of the in-game situation.

\section{Translation Acceptability of the Indonesian Fan Subtitle "I WON!!!"}

Table 13 shows that most of the translations are classified as ideal-acceptable 
translation which has 263 data $(80.2 \%)$ out of 328 data. Besides, the acceptable translation is the least frequent number with 12 data (3.7\%) out of 323 data. Meanwhile, there are 32 data
(9.8\%) from 328 data which are considered unacceptable translation. Moreover, the total number of failed translations is 21 data (6.4\%) out of 328 data.

Table 13: The Translation Acceptability of the Fan Subtitle "I WON!!!"

\begin{tabular}{|c|c|c|c|}
\hline No & Acceptability Degree & Frequency & Percentage \\
\hline 1 & Ideal Acceptable (I-Acc) & 263 & $80.2 \%$ \\
\hline 2 & Acceptable (Acc) & 12 & $3.7 \%$ \\
\hline 3 & Unacceptable (Uncc) & 32 & $9.8 \%$ \\
\hline 4 & Failed (F) & 21 & $6.4 \%$ \\
\hline & Total & 328 & $100.0 \%$ \\
\hline
\end{tabular}

The researcher provides some sample data for the four translation acceptability degrees which are found in the fan subtitle of the video entitled "I WON!!!": (1) IdealAcceptable, (2) Acceptable, (3) Unacceptable, and (4) Failed. The sample data of Ideal Acceptable Translation are presented below.

Table 14: Examples of ideal acceptable translation

\begin{tabular}{|c|c|c|c|}
\hline SL Code & SL & TL Code & $\mathrm{TL}$ \\
\hline $\begin{array}{l}\text { 158/SL/t.08:28.15 } \\
-08: 30.06\end{array}$ & $\begin{array}{l}\text { Fuck! The map is } \\
\text { getting smaller. }\end{array}$ & $\begin{array}{l}\text { 158/TL/t.08:28.15 - } \\
08: 30.06\end{array}$ & $\begin{array}{l}\text { Sial. Petanya } \\
\text { semakin } \\
\text { mengecil. }\end{array}$ \\
\hline $\begin{array}{l}\text { 54/SL/t.02:39.12 - } \\
02: 40.12\end{array}$ & $\begin{array}{l}\text { I'll be taking all your } \\
\text { shit. }\end{array}$ & $\begin{array}{l}\text { 54/TL/t.02:39.12 - } \\
02: 40.12\end{array}$ & $\begin{array}{l}\text { Akan kuambil } \\
\text { semua } \\
\text { barangmu. }\end{array}$ \\
\hline
\end{tabular}

Both sample data are considered accurate, clear, and natural. In datum number 158 and 54 , the meanings from the SL are translated accurately into the TL. Moreover, the TL form conveys the intended meaning of the SL clearly. The word forms of the TL are in the normal form in Indonesian which make them natural.
The findings show that there are data which only meet two out of three criteria of acceptability. These data belong to acceptable translation, which are represented by two examples below.

Table 15: Examples of acceptable translation

\begin{tabular}{clll}
\hline \multicolumn{1}{c}{ SL Code } & \multicolumn{1}{c}{ SL } & \multicolumn{1}{c}{ TL Code } & \multicolumn{1}{c}{ TL } \\
\hline 132/SL/t.07:03.01 - & cause I have a & 132/TL/t.07:03.01 & Aku punya \\
07:04.03 & shotgun. & $07: 04.06$ & Shotgun di sini. \\
$60 /$ SL/t.03:07.00 & I can hear that & 60/TL/t.03:07.00 - & Aku bisa \\
- 03:08.08 & fucker. & $03: 08.08$ & mendengar \\
& & & bajingan itu. \\
\hline
\end{tabular}

In datum number 132, the translation is not accurate because the deletion of the conjunction "cause", informal form of because, is not necessary. The word "cause" is a conjunction. This word is important to be translated in order to produce an accurate translation which preserves the information from the SL. However, the translation is clear and natural because the TL form is in the 
natural form which is appropriate and conveys the intended meaning of the SL implicitly.

In datum number 60 , the translation is accurate because the meaning of the SL is well preserved. Unnecessary addition and deletion do not occur. Moreover, it is clear because the TL form conveys the intended meaning of the SL. However, the translation is not natural because the word "that fucker" is translated into "bajingan itu". Meanwhile, the word "bajingan" in the TL is considered a very strong swearing word in the target language sociocultural context.

According to Larson (1984), a translation is considered unacceptable if the translation consists of only one out of the three criteria of ideal translation. Therefore, if a translation only possesses naturalness, or clarity, or accuracy, the translation is considered unacceptable. Based on the findings, there are 32 data out of 328 data. The sample data of the unacceptable translation is presented below.

Table 16: Examples of unacceptable translation

\begin{tabular}{ll|l|l}
\hline \multicolumn{1}{c}{ SL Code } & \multicolumn{1}{c}{ SL } & \multicolumn{1}{c}{ TL Code } & \multicolumn{1}{c}{ TL } \\
\hline 82/SL/t.04:24. & Yeah, boy! & 82/TL/t.04:24.10 - & \multicolumn{1}{c}{ YEAH NAK! } \\
10- 04:25.25 & & $04: 25.25$ & \\
\hline 185/SL/t.09:59 & He did not see me. Did he & 185/TL/t.09:59.04 - & Dia tidak melihatku. \\
$.04-10: 02.12$ & just park in front of me? & $10: 00.60$ & Dia hanya parkir di \\
& & & depanku? \\
\hline
\end{tabular}

In datum number 82 , the translation is considered not accurate and not natural, but it is clear. The word "boy" which is an interjection is mistranslated into "nak". The word "nak" in TL (Indonesian) refers to the addressing name of a daughter or son because the word "nak" is from the word "anak". Furthermore, the word "nak" is not suitable or not natural in the context because the meaning of the SL is the interjection that expresses the happiness in the game. Since the translation is not accurate and not natural, the researcher proposes to change the TL into "Oke, bro!" or "Oke, brur!"

In datum number 185, the translation is considered unacceptable because the translation is not accurate and not clear due to the time duration of the TL text. However, the translation is natural because the target language text uses the natural word form which is appropriate in the target language. In order to make a better translation, the researcher proposes to set the subtitle time appearance duration correctly with the SL.

A failed translation is a translation which does not transfer the meaning of the SL to TL accurately, give clear meaning, and present natural word structure of the TL. Some data represent this category.

Table 17: Examples of failed translation

\begin{tabular}{|c|c|c|c|}
\hline SL Code & SL & TL Code & TL \\
\hline $\begin{array}{l}\text { 52/SL/t.02:34. } \\
09-02: 35.29\end{array}$ & $\begin{array}{l}\text { Fucking range on the } \\
\text { shotgun, man! }\end{array}$ & $\begin{array}{l}\text { 52/TL/t.02:34. } \\
09-02: 35.29\end{array}$ & $\begin{array}{l}\text { Jarak yang lumayan untuk } \\
\text { Shotgun, 'kan? }\end{array}$ \\
\hline $\begin{array}{l}\text { 170/SL/t.09:05 } \\
.15-09: 07.20\end{array}$ & $\begin{array}{l}\text { Call me a Swedish } \\
\text { pussy. }\end{array}$ & $\begin{array}{l}170 / \text { TL/t.09:06 } \\
.06-09: 08.14\end{array}$ & $\begin{array}{l}\text { Panggil aku orang Swedia } \\
\text { pecundang. }\end{array}$ \\
\hline
\end{tabular}


In datum number 52 , the translation is not clear because the intended message of the SL is not conveyed in the TL. It is not accurate because the interjection in the SL is translated into a question in the TL which shows uncertainty. Moreover, the translation loses the naturalness of the translation because the use of the question tag “....,'kan?" in the TL. The correct and natural form of the question tag should be “..., bukan?". Therefore, the researcher proposes a suggestion to make the translation ideal-acceptable into "Jarak shotgunnya jauh banget, bro!".

In datum number 170 , the translation is considered failed because the translation does not possess the accuracy, the clarity, and the naturalness criteria. Firstly, the translation is not accurate because indeed all elements of the SL are translated into TL, but the sentence structure in TL gives ambiguous meaning. Secondly, the translation is not in the natural form of the TL because the translation is not meaning-based translation but form-based translation. Thirdly, due to the wrong sentence structure of the TL and not in the natural form of the TL, the sentence flow is not smooth. Therefore, the reseracher proposes to change the translation into "Panggil aku pecundang dari Swedia" to make the translation idealaccceptable.

The relation between the implemented subtitling strategies and the result of the translation acceptability degree analysis can be shown in Table 18.

Table 18: Strategies and Acceptability

\begin{tabular}{|c|c|c|c|c|c|c|c|c|c|}
\hline \multirow[t]{2}{*}{ No } & Acceptability Degree & \multicolumn{2}{|c|}{ I-Acc } & \multicolumn{2}{|c|}{ Acc } & \multicolumn{2}{|c|}{ Uncc } & \multicolumn{2}{|l|}{$\mathrm{F}$} \\
\hline & Subtitling Strategy & $\bar{\Sigma}$ & $\%$ & $\Sigma$ & $\%$ & $\bar{\Sigma}$ & $\%$ & $\bar{\Sigma}$ & $\%$ \\
\hline 1. & Transfer $(n=134)$ & 115 & 86 & 2 & 1 & 15 & 11 & 2 & 1 \\
\hline 2. & Taming (n=73) & 57 & 78.1 & 6 & 8 & 9 & 13 & 1 & 1 \\
\hline 3. & Deletion $(n=37)$ & 36 & 97 & - & - & 1 & 3 & - & - \\
\hline 4. & Expansion $(n=26)$ & 21 & 81 & 1 & 4 & 3 & 12 & 1 & 4 \\
\hline 5. & Paraphrase $(n=19)$ & 17 & 89.5 & - & - & 2 & 10 & - & - \\
\hline 6. & Resignation ( $\mathrm{n}=17)$ & - & - & - & - & - & - & 17 & 100 \\
\hline 7. & Condensation $(n=9)$ & 6 & 67 & 1 & 11 & 2 & 22 & - & - \\
\hline 8. & Imitation $(\mathrm{n}=9)$ & 8 & 89 & 1 & 11 & - & - & - & - \\
\hline 9. & Transcription $(n=2)$ & 1 & 50 & 1 & 50 & - & - & - & - \\
\hline 10. & Decimation $(n=2)$ & 2 & 100 & - & - & - & - & - & - \\
\hline Tot & & 263 & & 12 & & 32 & & 21 & \\
\hline
\end{tabular}

As shown in Table 18, there are some subtitling strategies which are effective in translating the meaning from SL to TL. They are characterized by the high percentage of each translation degree, and are considered ideal-acceptable (I-Acc) and acceptable (Acc). The effective subtitling strategies are transfer, taming, deletion, expansion, paraphrase, condensation, imitation, transcription, and decimation. The transfer subtitling strategies is the most implemented subtitling strategy with the 134 data in which 115 data out of 134 data are considered as ideal-acceptable (IAcc) and 2 data are considered as acceptable (Acc), so that there are $87 \%$ acceptable translations from 134 data which implemented using transfer. In contrast, there is one subtitling strategy which shows the high results of the failed translation. The subtitling strategy is resignation. There are 17 data which are the implementation of the resignation subtitling strategy. However, all of the data are considered as failed translation (F) because the resignation subtitling strategy is a zero-translation due to the inability in translating the message from SL to TL.

\section{Conclusion}

The first goal of this research is to find what subtitling strategies used in Indonesian fan subtitle of PewDiePie PUBG video. The 
subtitling strategies found in the Indonesian fan subtitle of PewDiePie PUBG video are expansion, transfer, paraphrase, transcription, imitation, decimation, condensation, resignation, deletion, and taming. The transfer strategy is the most dominant subtitling strategy because the utterances in the source language mainly can be translated directly by the literal word meaning in a complete and a correct way. The second goal is to find the translation acceptability degree of the Indonesian fan subtitle translation in PewDiePie PUBG video There are four translation acceptability degrees: idealacceptable, acceptable, unacceptable, and failed. Based on the findings, the idealacceptable translation is the most dominant degree which the total number of the data is 263 data out of 328 data (80.2\%). Meanwhile the acceptable translation degree is the least frequent degree with 12 data out of 328 data $(3.7 \%)$. The unacceptable translation has the total number 32 data out of 328 data (9.8\%). Meanwhile, there are 21 data out of 328 data $(6.4 \%)$ categorized into failed translation. The researcher recommends future researchers to conduct more studies on fan subtitles. Since this study focuses on the subtitling strategies and the translation acceptability, future researchers need to develop fan subtitle studies in order to know the benefits and the downside of fansubbing activities and fan subtitle products in sociocultural contexts, linguistic fields, and language learning environments.

\section{References}

Basari, A., \& Simanjuntak, N. V. M. (2016). Subtitling strategies in Real Steel movie. In LITE Journal, March 2016, vol, 12, no.1,pp. 17-36.

Bell, R. T. (1998). Psycholinguistic cognitive approaches. In M. Baker (1 ${ }^{\text {st }}$ Ed.), Routledge Encyclopedia of Translation Studies. London: Routledge, 1998.

Bowen, G.A. (2009). Document analysis as a qualitative research method. Qualitative
Research Journal, vol. 9, no. 2, pp. 27-40. Available at: <doi: 10.3316/QRJ0902027>.

Cintas, D. J., \& Sánchez, M. B. (2006). Fansubs: Audiovisual translation in an amateur environment. The Journal of Specialized Translation, July 2006, vol. 6, pp. 37-52.

Crescentini, A. (2009). Qualitative research articles: Guidelines, suggestions and needs. Journal of Workplace Learning, July 2009, vol. 21, no. 5, pp. 431-439.

Cresswell, J. (2007). Qualitative inquiry and research design: Choosing among five approaches (2nd ed.). Santa Barbara, CA: Sage Publication.

Feldman, G., Lian, H., Kosinski, M. \& Stillwell, D. (2017). Frankly, we do give a damn: The relationship between profanity and honesty. Social Psychological and Personality Science, January 2017, 8(7), 816-826. Available at: <doi: $10.1177 / 1948550616681055>$.

Google Help. (n.d). Contribute translated content. YouTube Help. Retrieved from https://support.google.com/youtube/an swer $/ 6054623$ ?hl=en accessed on November 25, 2018.

Gottlieb, H. (1992). Subtitling: A new university discipline. Teaching Translation and Interpreting, pp. 161-170. Amsterdam: John Benjamins, 1992.

Gottlieb, H. (1994). Subtitling: People translating people. Teaching Translation and Interperting 2, pp. 261-274. Amsterdam: John Benjamins, 1994.

Gottlieb, H. (2002). Titles on subtitling 19291999. An International Annotated Bibliography: Interlinguagl Subtitling for Cinema, TV, Video and DVD, vol. 34, no. 1, pp. 215-397.

Hastuti, D.E. (2015). An analysis on subtitling strategies of Romeo and Juliet movie. Register, June 2015, vol. 8, no. 1, pp. 57-80. 
Hatim, B., \& Munday, J. (2004). Translation: An advanced resource book. New York: Routledge, 2004.

Kiellberg, F. [PewDiePie]. (2017), June 11. I Won!!! [Video file]. Available at: $<$ https://youtu.be/p8Kp18WpxQw>.

Kusumastuti, R.A. (2017). The acceptability of Indonesian - English translation of the Scene Plaques in Fort Vredeburg museum based on Larson's theory. Yogyakarta: Sanata Dharma University.

Lakarnchua, 0. (2015). Examining the potential of fansubbing as a language learning activity. Innovation in Language Learning and Teaching, June 2015. pp. 113. Available at: <doi: 10.1080/17501229.2015.1016030>.

Larson, L. M. (1984). Meaning-based translation: A guide to cross-language equivalence. New York: University Press of America, 1984.

Nababan, M., Nuraeni. A., \& Sumardiono. (2012). Pengembangan model penilaian kualitas terjemahan. Kajian Linguistik dan Sastra, June 2012, vol. 24, no. 1, pp. 39-57.

Nida, A.E., \& Taber, R. C. (1974). The theory and practice of translation. Leiden: E.J. Brill, 1974.

Nore., Udin. W., Scodz., \& Sumapraja. A.H. (2017). I Won!!! [Subtitle file]. Available at: <https://youtu.be/p8Kp18WpxQw>.

Pradhana, B. (2016). Translation methods of a fansub by kyuubisubs of episode 74 of the Fairytail anime. Jurnal Linguistik Terapan, May 2016, vol. 6, no. 1, pp. 13-25.

The Sims Supply. (2018), October 29. Everything about The Sims 4 Get Famous! (Acting, Career, New World + More!) [Video file]. Available at: <https://youtu.be/Z9tVkCDg1YU>.

Wang, F. (2014). Similarities and differences between fansub translation and traditional paper-based translation. Theory and Practice in Language Studies,
September 2014, vol. 4, no.9, pp. 19041911.

Wang, P. (2009). "Hidden epidemic" Where is the way? - "Subtitle group" translated aspects. Movie Review, vol. 17, pp. 63-64. 